\title{
Views from two mountains: exploring climate change impacts on traditional farming communities of Eastern Africa highlands through participatory scenarios
}

\author{
Claudia Capitani ${ }^{1}$ (D) Weyessa Garedew ${ }^{2} \cdot$ Amsalu Mitiku $^{2} \cdot$ Gezahegn Berecha $^{2}$. \\ Binyam Tesfau Hailu ${ }^{3}$. Janne Heiskanen ${ }^{4}$. Pekka Hurskainen ${ }^{4}$. Philip J. Platts ${ }^{5}$. \\ Mika Siljander $^{4} \cdot$ Fabrice Pinard $^{6} \cdot$ Tino Johansson $^{4} \cdot$ Robert Marchant $^{1}$
}

Received: 1 February 2018/Accepted: 11 August 2018/Published online: 29 August 2018

(C) The Author(s) 2018

\begin{abstract}
African mountains are characterized by high levels of biodiversity and provide ecosystem services to millions of people. Due to steep environmental gradients, growing human populations and geographical isolation, these coupled socioecological systems are highly vulnerable to climate change impacts. The capacity of local stakeholders to anticipate future changes and to assess their potential impacts is paramount for enhancing adaptation and resilience. Here we apply a participatory scenario development framework in two parts of the Eastern Afromontane Biodiversity Hotspot: Taita Hills in Kenya and Jimma rural area in Ethiopia. In each area, we facilitated local stakeholders in envisioning adaptation scenarios under projected climate changes by mid-21st century, and assessed the potential impacts of these pathways on land use and land cover. In the Taita Hills, under a business-as-usual scenario, human population and activities concentrate at high elevation, triggering cascade effects on remnant forest cover, biodiversity and ecosystem services. Alternative adaptation scenarios envisage reforestation associated with either improved agricultural practices or ecosystem restoration. In the Jimma area, rising temperatures are expected to disrupt traditional coffee production under a business-as-usual scenario, resulting in the loss of coffee-forest canopies and reduction of forest-dependent biodiversity. Alternative adaptation scenarios envisage either expansion of commercial coffee plantations or expansion of agroforestry, including traditional coffee farming. In the both Taita and Jimma, adaptation pathways present trade-offs between provisioning, supporting and regulating services, and between livelihoods and biodiversity conservation. Our findings encourage the use of multidisciplinary, bottom-up approaches for developing locally tailored, climate-smart and sustainable adaptation pathways.
\end{abstract}

Keywords Adaptation - Sustainable development goals · Land changes · Agroforestry · Coffee farming · Resilience

Handled by Osamu Saito, United Nations University Institute for the Advanced Study of Sustainability, Japan.

Electronic supplementary material The online version of this article (https://doi.org/10.1007/s11625-018-0622-x) contains supplementary material, which is available to authorized users.

Claudia Capitani

Claudia.capitani@york.ac.uk

Extended author information available on the last page of the article

\section{Introduction}

Along with population growth (Canning et al. 2015) and anthropogenic land use and land cover changes (Brink et al. 2014, Schmitz et al. 2014), climate change is amongst the greatest future challenges for many African countries (Niang et al. 2014, Gasparatos et al. 2017). Tackling climate change then will have substantial influence on the achievement of sustainable development goals (SDGs), at country and local levels, such as poverty reduction, food security, and ecosystems conservation and restoration (Fleurbaey et al. 20142030 Agenda for Sustainable Development). 
In mountain areas, the steep climatic gradients and scarcity of observation make it difficult to assess and model potential climate change impacts at local scale, and therefore, to plan adaptation strategies. These adaptation strategies require a holistic approach explicitly addressing non-climatic factors (Räsänen et al. 2016), including common montane traits such as geographical isolation and remoteness and adaptive responses to altitudinal gradient which increase either vulnerability or resilience to climate. East African mountain ecosystems are highly productive agricultural areas supporting large populations that have experienced intense migration flows and extensive land cover changes over the last century (Marchant et al. 2018). In montane areas of Ethiopia and Kenya, projected climate change by the mid-21st century is characterised by an increase of temperature, increased frequency of extreme events, and uncertainty of precipitation patterns; wetter rainy seasons are expected in Kenya and prolonged aridity in Ethiopian highlands (Platts et al. 2015). Temperature increases could benefit maize and bean production at high elevation (Adhikari et al. 2015), thereby implying a potential shift upwards of maize farming, but also potential land use conflicts. However, climate change effects are likely to extend to pest-host interactions and plant defence mechanisms which ultimately affect crop suitability (Calatayud et al. 2016, Ntiri et al. 2016, Ngowi et al. 2017). Globally suitable agro-climatic zones for growing Coffee arabica are expected to significantly diminish, although increased temperature could favour its production at higher elevation and close to the Equator (Ovalle-Rivera et al. 2015). With higher temperatures increased potential damage by coffee berry borer Hypothenemus hampei (Jaramillo et al. 2011) and coffee leaf rust Hemileia vastatrix disease (Toniutti et al. 2017) are expected.

In such uncertain and complex picture, understanding how local stakeholders can respond to future changes, and building their capacity of anticipating potential impacts of alternative adaptation strategies on ecosystem services, biodiversity and livelihoods are paramount for enhancing adaptation and social-ecological system resilience. Scenario analysis can contribute to these objectives and has been applied in a wide range of studies to address environmental and sustainability problems (Kishita et al. 2016). In the climate change context, scenarios respond to the needs of addressing knowledge gaps in potential future vulnerability and acquired resilience, and to inform decision-making on potential trade-offs between goals and expectations (e.g., maladaptation) (McDowell et al. 2016). By addressing multiple dimensions, scenarios can integrate projected climate change impacts (outcome vulnerability) with socio-economic and environmental trajectories (context vulnerability) (O'Brien et al. 2007, Joakim et al. 2015). The scenario framework offers the opportunity to tackle climate change adaptation pathways by engaging multiple stakeholders (Jurgilevich et al. 2017) and by exploring potential positive opportunities deriving from changes (McDowell et al. 2016). Stakeholders' engagement brings the mediating effect of indigenous knowledge, response to local climate effects (Savo et al. 2016), and the potential barriers of community capacity and willingness to adapt. The use of participatory, place-based and bottom-up scenarios frameworks for biodiversity and ecosystem services assessment within landscapes is highly recommended, though still limited (IPBES 2016, Kok et al. 2017). Furthermore, holistic scenarios integrating different challenges such as climate changes and land use and land cover changes are lacking (Kishita et al. 2016).

In this study, we apply a participatory scenario modelling framework (Capitani et al. 2016) to assess potential societal responses to the impacts of climate change by the mid-21st century, and model consequent land use and land cover change scenarios under different livelihood futures as guided by communities' members in the areas under investigation. We focus our analysis on two montane sites of the Eastern Afromontane Biodiversity Hotspot (Mittermeier et al. 2011), the Taita Hills, Kenya, and a montane area north-west of Jimma, Ethiopia (Fig. 1). In the Taita Hills, communities rely on a variety of staple and cash crops, timber and non-timber forest products, while in the Jimma study area, coffee production is an important income source, coupled with staple food crops production. Beside livelihood strategies, the two study areas differ by timing of deforestation trends (past century versus past decades), human population density (high versus low) remoteness and isolation degree (higher versus lower access to markets and services), rainfall patterns (bimodal versus unimodal) and projected changes (increased versus decreased rainfall). We present potential adaptation pathways to projected climate changes in these two socialecological systems and discuss their implications in relation to multiple ecosystem services, and their interactions with SDGs.

\section{Materials and methods}

\section{Taita Hills}

The Taita Hills study area covers approximately $895 \mathrm{~km}^{2}$ ranging between 600 and $2200 \mathrm{~m}$ above sea level (m a.s.1.) in the Taita Taveta County, Kenya (Fig. 1). In this study we refer to three altitudinal zones in the study area identified in relation to agro-ecological zones and main villages location: low zone (below $1200 \mathrm{~m}$ a.s.l.), middle zone (1200-1700 m a.s.1.), and middle-high zone (above 1700 $\mathrm{m}$ a.s.1.). The Taita Hills are located at the junction of the 


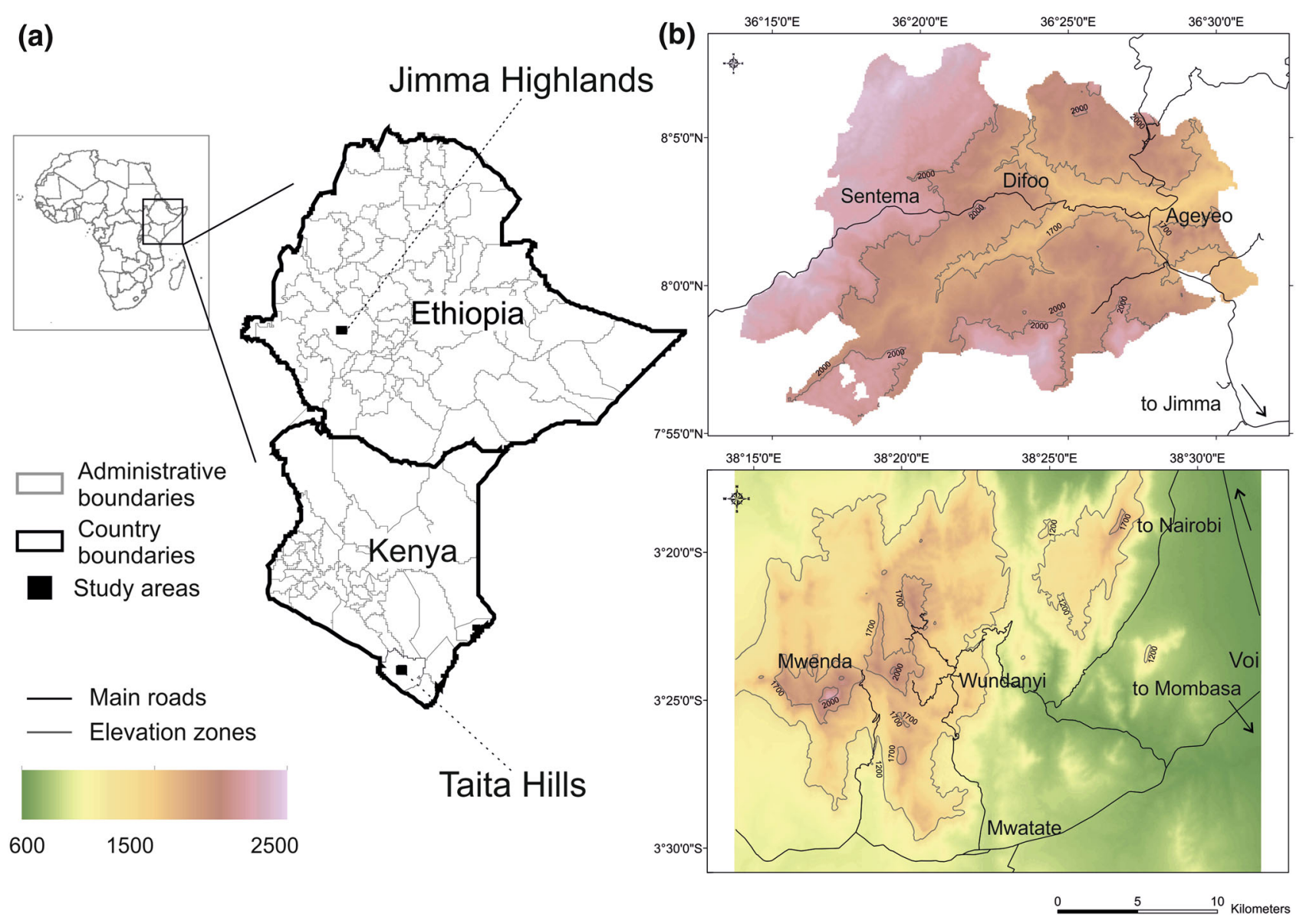

Fig. 1 Location of study areas in East Africa a, and elevation (SRTM-90, Jarvis et al. 2008) and contours of the reference elevation zones in the Taita Hills and Jimma study areas $\mathbf{b}$

main highway between the cities of Nairobi and Mombasa, and the main highway towards the Tanzanian border. In Taita Taveta County, population grew from circa (ca.) 111,000 in 1969 to ca. 285,000 in 2009 and is projected to reach ca. 345,000 by 2017 (Kenya National Bureau of Statistics (KNBS) 2009). Accordingly, population density has increased in the Taita Hills, reaching up to 1540 persons $/ \mathrm{km}^{2}$ in the main villages of the middle zone (Kenya National Bureau of Statistics (KNBS) 2009), with consequent agricultural expansion, heavy degradation of the indigenous cloud forests and increased water stress (Maeda 2012). Only $1 \%$ of the original forest cover remains preserved as scattered cloud forest (Pellikka et al. 2009). Agriculture is the main income source, dominated by maize, horticulture and fruit trees. Livestock keeping is limited to the low zone where off-farm income is mainly related to tourism, transport and mining. In this region, climate is influenced by the Inter-Tropical Convergence Zone (ITCZ) which leads to a bimodal rainfall pattern, with long rains during March-May/June and short rains in October-December, corresponding to the temperature peak (Clark and Pellikka 2009). Precipitation and temperature vary across the area, influenced by elevation and aspect (Table 1). By the mid-21st century, under Representative Concentration Pathway (RCP) 4.5 scenario (IPCC 2014), mean annual temperature and mean annual rainfall are projected to increase by $1.8^{\circ} \mathrm{C}$ and $72 \mathrm{~mm} / \mathrm{km}^{2}$ year ${ }^{-1}$ respectively, on average across the study area (AFRICLIM 3.0, Platts et al. 2015, Table 1); increased variability of season onset and duration is also expected, particularly for short rains.

\section{Jimma area}

The Jimma study area covers a small portion $\left(425 \mathrm{~km}^{2}\right)$ of the Didessa river catchment in southwestern Ethiopia between 1400 and $2400 \mathrm{~m}$ a.s.l., in the Jimma administrative zones (Fig. 1). Similar to the Taita Hills, we identified three altitudinal zones in the study area corresponding to agro-ecological and village zones: middle zone (below $1700 \mathrm{~m}$ a.s.l.), middle-high zone (1700-2000 m a.s.1.), and high zone (above $2000 \mathrm{~m}$ a.s.l.). The area is regarded to be a region of endemic C. arabica (Mittermeier et al. 2011). The Jimma administrative zone 
Table 1 Climate parameters baseline and projected values for the representative concentration pathway (RCP) 4.5 scenario by mid-21st century (IPCC 2014), derived from 1-km resolution temperature and rainfall spatial grids (AFRICLIM 3.0, Platts et al. 2015)

\begin{tabular}{|c|c|c|c|c|}
\hline & \multicolumn{2}{|l|}{ Taita Hills } & \multicolumn{2}{|l|}{ Jimma } \\
\hline & Baseline & $\begin{array}{l}\text { RCP } 4.5 \text { to baseline } \\
\text { change }\end{array}$ & Baseline & $\begin{array}{l}\text { RCP } 4.5 \text { to baseline } \\
\text { change }\end{array}$ \\
\hline $\begin{array}{l}\text { Mean annual temperature (mean of monthly means, } \\
\left.{ }^{\circ} \mathrm{C}\right)\end{array}$ & $22.0(16.7-24.9)$ & $1.8(1.8-1.9$ & $18.7(17.1-20.8)$ & \\
\hline Mean annual rainfall (sum of monthly rainfall, $\mathrm{mm}$ ) & $1022(644-1442)$ & $71.9(44-94)$ & $1782(1642-1839)$ & $-31(-57$ to -11$)$ \\
\hline $\begin{array}{l}\text { Rainfall seasonality (standard deviation over monthly } \\
\text { values, } \mathrm{mm} \text { ) }\end{array}$ & $60(40-91)$ & $8(5-10)$ & $106(98-114)$ & $3(+1$ to 5$)$ \\
\hline $\begin{array}{l}\text { Number of dry months (dry/arid if monthly moisture } \\
\text { index }<0.5 \text { ) }\end{array}$ & $7(4-8)$ & $-0.1(-1$ to 1$)$ & $4(4-5)$ & $0.4(0$ to +1$)$ \\
\hline
\end{tabular}

The mean and range (in parenthesis) of the variables spatial mean across each study area are reported

had an estimated population of ca. 2487,000 in the 2007 census, increased by $27 \%$ over the 1994 census; in the study area, the highest population density was recorded in a census unit of the low zone (204 persons $/ \mathrm{km}^{2}$, CSA (Central Statistical Agency of Ethiopia) 2007). In the Jimma study area, forest cover dominates the landscape above $1750 \mathrm{~m}$ a.s.l. While agriculture has expanded at lower elevation (Hailu et al. 2014, 2015a). Livelihood is mainly based on subsistence agriculture, in particular maize, but organic coffee farming is an important income source. The majority of farmers in the study area collect berries from wild plants in natural forests or from semiforest coffee systems (Denu et al. 2016), characterized by thinning of canopy trees, removing of ground vegetation and enrichment of empty spaces by transplanting naturally regenerating seedlings of coffee (Teketay 1999).

Deforestation has occurred in the southwestern Ethiopian highlands due to population growth and conversion to farmland in the past decades (Hylander et al. 2013, Hailu et al. 2015a), while many remnant forest patches coincide with suitable areas for coffee farming and, to a lesser extent, sacred forest groves (Denu and Belude 2012).

This part of the country is characterised by a humid subtropical climate influenced by the ITCZ (Table 1). A unimodal rainfall pattern falls between February and May and September, corresponding to the temperature peak. By the mid-21st century, under RCP 4.5 scenario (IPCC 2014), mean annual temperature may increase by $2.3{ }^{\circ} \mathrm{C}$ and mean annual rainfall decrease by ca. $31 \mathrm{~mm} / \mathrm{km}^{2}$ year ${ }^{-1}$ are expected on average across the study area along with increased duration of dry season (Table 1).

\section{Scenarios development}

The scenarios building framework follows a mixed approach (Capitani et al. 2016) whereby local stakeholders develop qualitative and semi-quantitative scenarios guided by a team including facilitators and modellers. The modellers then translate this information into quantitative and spatially explicit outputs. The final outputs are created following subsequent stakeholders' validation of preliminary results.

In the Taita Hills, we held three multi-stakeholder workshops between February and October 2015. The complex landscape in this area required an additional workshop compared to the framework design to analyse in details potential future land changes and their spatial patterns. Results were validated in a synthesis workshop in September 2016. In the Taita Hills, we engaged 30 participants in scenarios development including 14 farmers, 8 government officers, 2 non-governmental organisations delegates, and 6 members of associations for women and disabled people. The final feedback and validation workshop gathered 21 people, a stratified sub-sample of the scenario development group including farmers and delegates of local authorities and associations. In the Jimma area, two workshops were conducted in June 2015 and September 2016 and the results were validated in a synthesis workshop in August 2017. In the Jimma area, we engaged 32 participants in scenarios development including 18 local farmers, 10 academics and four local officers. The feedback and validation workshop engaged 24 people including 18 local farmers, five academics and a local officer from the forestry and wildlife office. The scenario development workshops were organized in parallel to the development of the strategic plan for climate change (CC) adaptation interventions (Owidi et al. 2015a, 2015b), which required participatory mapping of experienced climate- and non-climate driven changes in the area, and identification of high risk areas prioritized for action. A sub-sample of the county-level stakeholder groups targeted by this process was involved in the scenarios development process that was meant to address potential impacts of alternative adaptation pathways over a long-term. In both areas, 
stakeholders' analysis was facilitated by long-term knowledge and research activities of the project partners in the areas. Stakeholders were selected by following the criteria of representativeness of different communities across the elevation gradient and of inclusion of multiple users and managers of land and water resources. Limited evidence of adaptation initiatives targeting socioeconomically disadvantaged or vulnerable community members has been reported (Ford et al. 2015), and therefore, we encouraged participation of women and people with some form of disability.

In the initial workshops for scenarios development, participants organised in focus groups discussed land management and climatic variability observed in the past. Then they identified potential socio-economic and environmental trajectories and their drivers under future projected climate conditions and alternative adaptation strategies. In the following workshops, the participants described spatially explicit patterns of expected land use and land cover changes under the different scenarios by defining the likelihood of change (on a 0-4 scale) and biophysical and socio-economic factors influencing it.

Land use and land cover change scenarios were modelled using 100 m-resolution baseline maps obtained resampling high resolution land use and land cover maps for the Taita Hills (Clark and Pellikka et al. 2009, Heikinheimo 2015) and for the Jimma area (Hailu et al. 2014, 2015b). Expected future land use and land cover changes were quantified over a 35-year period, based on past trends for cropland expansion and deforestation rates from remote sensing analysis (Clark and Pellikka et al. 2009, Heikinheimo 2015 for the Taita Hills; land cover maps developed at the Regional Centre for Mapping of Resources for Development (RCMRD)/SERVIR-Eastern and Southern Africa for the Jimma area) and on expected scenario trajectories developed during the multi-stakeholder workshops (Supplementary 1a and 1b). Therefore, the presented scenarios represent a potential quantification within the range of the envisaged trajectories. The spatial pattern of land use and land cover changes expected by workshops participants were simulated by composite indicators of likelihood of change built from high resolution spatial datasets, including mid-21st century projections temperature and rainfall regime changes derived from AFRICLIM 3.0 (Platts et al. 2015), population distribution (Worldpop, Lloyd et al. 2017), elevation and slope (SRTM 90, Jarvis et al. 2008), rivers and roads extracted from satellite image datasets. In the final validation and feedback workshops stakeholders provided information that was used to refine the scenarios. Furthermore we elicited the participants' reflection on potential impacts on ecosystem services state (e.g., increase, decline, or stable) under the proposed alternative scenarios compared to the current situation.

\section{Results}

\section{Taita Hills}

In the Taita Hills, under assumptions of increased rainfall and temperature, and increase in seasonal regime variability by mid-21st century, we developed three scenarios (Supplementary 1a): opportunistic coping strategy (business as usual, BAU); integrated adaptation focused on agriculture, the "food production" (FP); integrated adaptation focused on forests and ecosystem services, the "green integration" (GI). Under the BAU scenario individual coping strategies and not-integrated community interventions persist. Cropland increases by $5 \%$ at expense of woodland, thicket and forest $(-13,-6$ and $-21 \%$, respectively, Table 2), despite ban on logging. Cropland expansion is expected in the middle and middle-high zones, driven by productivity decrease, increased crop suitability at higher altitudes and increased demand (Fig. 2b-e). Demand for more cropland for ensuring staple food production follows the decline of soil fertility and land productivity, and changes in agro-ecological zones. Abandoned farmland is encroached by shrubs and built-up areas. Degradation of wooded land leads to an increase of shrub lands in the low zone. Forest plantation cover increases by $18 \%$ replacing cropland and woodland.

In the Taita Hills adaptation scenarios, new land is converted into agriculture despite of changed climate

Table 2 Surface of land use and land cover classes (hectares) in the Taita Hills in the 2011 baseline map (Heikinheimo 2015) and in the business as usual (BAU), food production (FP) and green integration (GI) scenarios maps

\begin{tabular}{lrrrr}
\hline Land use and land cover class & Baseline & BAU & FP & \multicolumn{1}{l}{ GI } \\
\hline Cropland & 38,873 & 40,834 & 45,193 & 40,609 \\
Shrubland & 16,332 & 16,028 & 14,778 & 15,427 \\
Thicket & 19,813 & 18,668 & 14,893 & 18,383 \\
Woodland \& agroforestry & 6076 & 5296 & 5976 & 6044 \\
Plantation forest & 2495 & 2938 & 2529 & 2392 \\
Indigenous forest & 803 & 633 & 1020 & 1527 \\
Grassland & 2210 & 2209 & 2211 & 2211 \\
Bare soil \& Built-up Areas & 854 & 850 & 856 & 863 \\
\hline
\end{tabular}

Expected future land use and land cover changes by mid 21st-century were quantified over a 35-year period from the baseline

Changes for water were not modelled, though we could expect a change in water production at catchment level and relative changes in water surface 

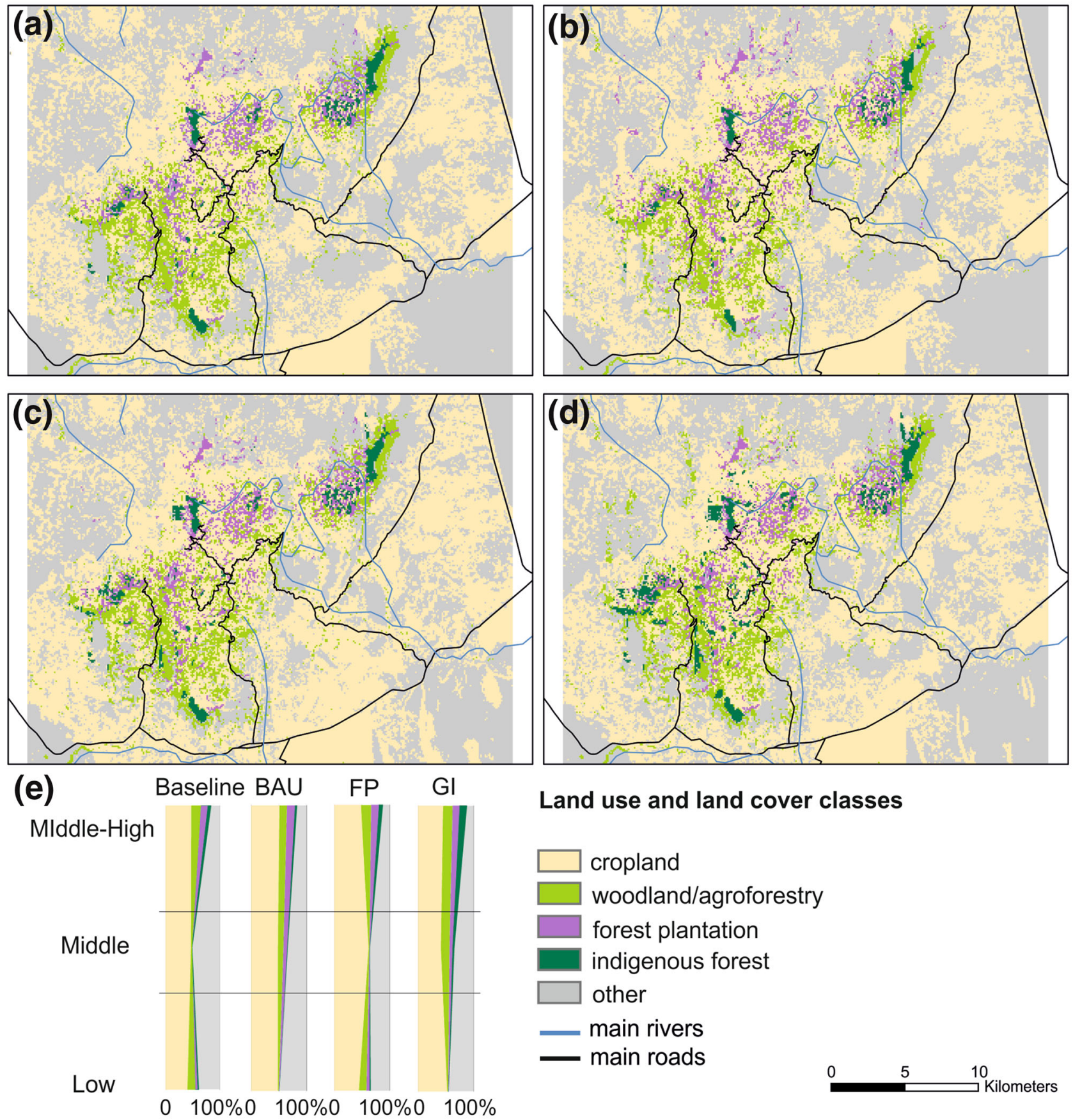

Fig. 2 Land use and land cover in the Taita Hills study area in the baseline (a, modified from Heikinheimo 2015), and in the business as usual (BAU, b), food production (FP, c) and green integration (GI, d)

conditions because of increased availability of water in these areas (following better land management and water harvesting infrastructure), improved water utilisation (e.g., drip irrigation), and increased use of drought resistant crops (Table S1.1). The food production scenario entails a modernisation of the traditional livelihood systems through improved agronomy practice and capacity. The agricultural mosaic landscape is maintained and expands $(+16 \%$,

Land use and land cover classes

$\square$ cropland

woodland/agroforestry

forest plantation

indigenous forest

other

\section{main rivers}

main roads

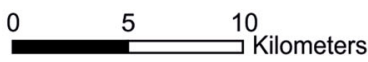

scenarios. At the bottom (e), share of land use and land cover classes $(\%)$ in the low $(<1200 \mathrm{~m}$ a.s.1.), middle $(1200-1700 \mathrm{~m}$ a.s.l. $)$ and middle-high $(>1700 \mathrm{~m}$ a.s.l. $)$ zones

Table 2), forest cover increases by $27 \%$, mainly in the middle-high zone (Fig. 2c-e). In the green integration scenario, most effort is directed to increasing indigenous forest cover $(+90 \%$, Table 2$)$, even by replacing exotic species, to improve water retention, regulation and purification, and humidity absorption in the hills. Income generating activities that are increasingly focused on the low zone result in partial re-naturalisation of the landscape in 
the middle and middle-high zones (Fig. 2d-e). In the both adaptation scenarios, infrastructures, particularly the road network, are improved.

\section{Jimma area}

In the Jimma study area, under the assumptions of increased temperature, slightly higher aridity and seasonal regime variability by mid-21st century, we developed three scenarios (Supplementary 1b): adaptation efforts are failing on the long-term because of low uptake by farmers (business as usual, BAU); adaptation is sustained by coffee industry expansion $(\mathrm{CI})$; and adaptation is sustained by agroforestry expansion (AGF). In this study area, stakeholders proposed to include new land use and land cover classes in the mid-21st century scenario maps, such as degraded land, commercial coffee plantations and agroforestry (Fig. 3). In the BAU scenario, climate change effects push a shift from traditional coffee farming and other cash crops (fruit trees and horticulture) to arable cropland for stable food production, with consequent high deforestation rate $(-40 \%$ forest cover, Table 3$)$. Stakeholders expected conversion of forest and cropland into degraded land and further expansion of exotic trees. Smallscale highly managed coffee plantations are established in the middle-high and high zones (Fig. 3b-e), to improve coffee production compared to wild and semi-managed coffee growing in the face of higher temperatures and increased disease incidence.

In the Jimma adaptation scenarios, adaptation is implemented through improved agricultural practices and adequate technology, particularly the use of disease resistant coffee seeds, old plants replacement and planting of shade trees; in addition, investment in social services and infrastructure enhance capacity building and access to credit (Table S1.2). This leads to decreased deforestation rates ( $-6 \%$ forest cover, Table 3$)$. In the coffee industry scenario, the cost of this transformative adaptation is taken over by commercial farms, along with coffee production. Coffee is almost exclusively produced in shaded but highly managed coffee plantations that expand into areas that have become suitable for coffee production (e.g., near the rivers and at higher elevation than in the baseline, Fig. 3c). This scenario implies a shift for local farmers from independent producers to farm workers or out-growers. In the AGF scenario, agroforestry expands over semi-opened forest patches, and across forest-cropland edges (Fig. 3d). Deforestation rate is low, and opened forest is managed for agroforestry. This system allows for production of both staple and cash crops, and sustains the maintenance of traditional semi-managed coffee plantation associated with beehives.
In the Jimma study area, the elevation pattern of land use and land cover changes is similar across the scenarios (Fig. 3e), and foresees an upward shift of land use intensification and forest conversion to farmland, coffee plantations or agroforestry. This pattern reflects population distribution, the altitudinal climate gradient and projected temperature changes expected to largely influence the spatial patterns of land use and land cover change by workshops participants.

\section{Qualitative assessment of impacts on biodiversity and ecosystem services}

In the both Taita Hills and Jimma, food provision, water regulation and climate regulation were indicated as key ecosystem services by workshops participants. Qualitative assessment of climate and land change scenarios impacts on ecosystem services and biodiversity relative to the baseline produced different outcomes across participants groups (Supplementary 1c). In the Taita Hills, workshop participants consistently expected decline for all services in the business as usual (BAU) scenario compared to the baseline, e.g., "food will be less available due to cropland degradation". Contrarily, improvement was expected for all services in the green integration scenarios (GI), e.g., "water regulation will improve following reforestation". For the food production scenario (FP), different groups highlighted different impacts between cultural/provisioning and regulating/supporting services relative to the current state, e.g., "soil erosion will be better regulated thanks to improved practices" versus "soil erosion will stay similar due to agricultural use" (Fig. S1a-b). Similarly, in the Jimma study area workshop participants consistently expected that all ecosystem services "will decline" in the business as usual while they "will improve" in the agroforestry scenarios. However, the academics and officer expected better impacts on cultural and provisioning services in the adaptation scenarios than the farmers groups, compared to the baseline (Fig. S1c-d). Expectations were particularly diverging for provision service in the coffee industry scenario, e.g., "wages will allow to buy more food" according to the academics and officer group, while the farmers group expected "food provision will be the same because some farmers are no longer producing it". Workshops participants generally expected biodiversity improvement under the adaptations scenarios in the two study areas and its decline under the BAU scenarios. Only the women group in Jimma expected the same biodiversity state in the adaptation scenarios as in the baseline. 

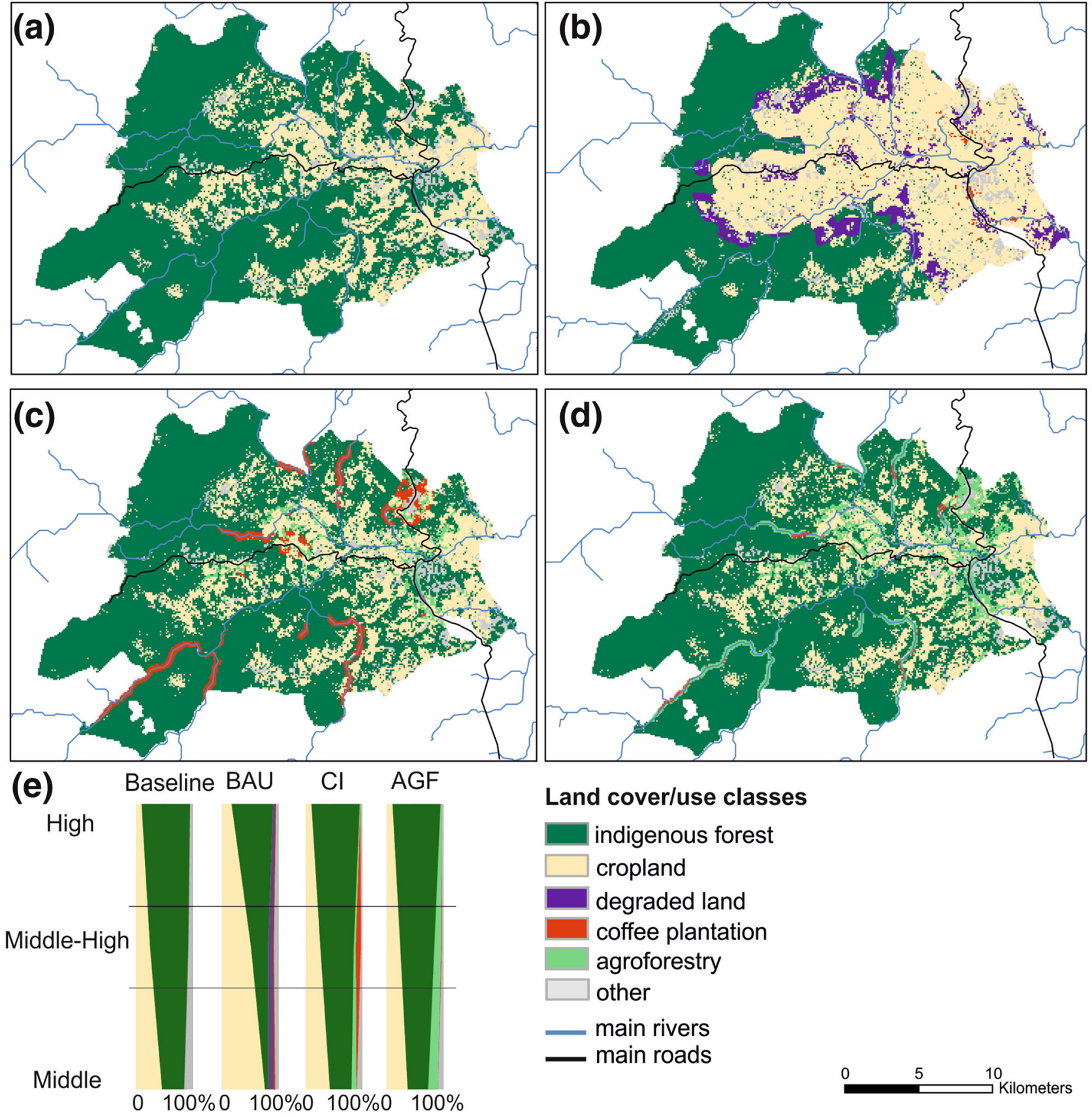

\section{Land cover/use classes}

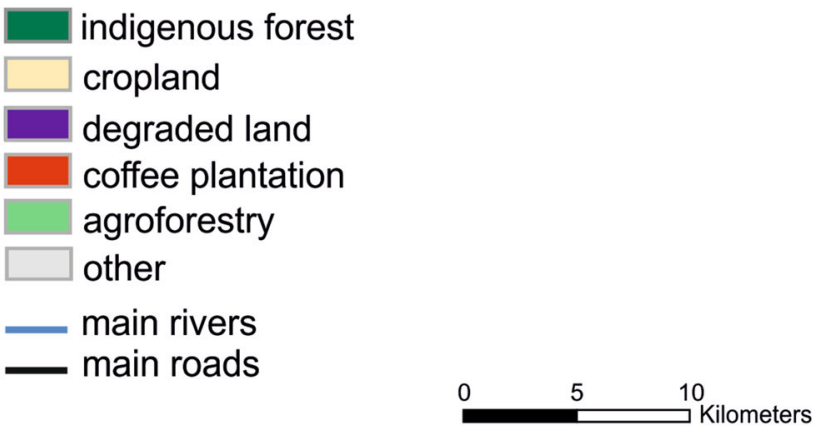

Fig. 3 Land use and land cover in the Jimma study area in the baseline (Hailu et al. 2014, 2015a) and in the business as usual (BAU, b), industrial coffee plantation (CI, c) and agroforestry with semimanaged coffee production (AGF, d) scenarios. At the bottom (e),

\section{Discussion}

In this study, we analysed potential adaptation pathways in response to climate change in two different socio-ecological systems of East African mountains, by applying a novel approach for mixed qualitative-quantitative scenarios co-production.

share of land use and land cover classes (\%) in the middle $(<1200 \mathrm{~m}$ a.s.l. $)$, middle-high (1200-1700 m a.s.l.) and high $(>1700 \mathrm{~m}$ a.s.1.) zones

This approach enriched climate scenarios narratives with the local perspectives and allowed integration of local knowledge into quantitative assessments, therefore, enhancing participants' sense of ownership and the outputs relevance. The scenario development and feedback process contributed to building the local stakeholders' capacity for long-term ecosystem management and climate adaptation. 
Table 3 Surface of land use and land cover classes (hectares) in the Jimma area in the 2008 baseline map (Hailu et al. 2014, 2015b) and in the business as usual (BAU), industrial heavy managed coffee plantations $(\mathrm{CI})$ and semimanaged coffee and agroforestry (AGF) scenarios

\begin{tabular}{lrrrr}
\hline Land use and land cover class & Baseline & BAU & CI & AGF \\
\hline Indigenous forest & 29,768 & 17,900 & 27,881 & 27,904 \\
Cropland & 9490 & 18,273 & 9563 & 8686 \\
Closed to open wood vegetation & 631 & 320 & 0 & 0 \\
Grassland & 2000 & 1410 & 1406 & 1406 \\
Exotic forest & 480 & 784 & 480 & 480 \\
Built-up areas $^{\text {aegraded land }}{ }^{\mathrm{a}}$ & 155 & 348 & 155 & 155 \\
Coffee plantation $^{\mathrm{a}}$ & & 3286 & 0 & 0 \\
Agroforestry $^{\mathrm{a}}$ & & 203 & 1701 & 200 \\
\hline
\end{tabular}

As Table 2

${ }^{\mathrm{a}}$ Classes not represented in the baseline map and added by workshop participants during scenarios development
However, participatory scenario development is a highly demanding process, which partly limits its application. Participatory approaches can be affected by power dynamics that in our study we prevented by encouraging individual participation and creating homogeneous focus groups by gender and social conditions. Additionally, these approaches require adequate communication tools with non-expert audiences. For example, in our study we used local landscapes images along with maps to represent current and scenario conditions.

\section{Stakeholders' perceptions on climate change}

Climate change is a long-term phenomenon difficult to detect, but people may shape their perception based on personal experience of increased climate variability (Weber 2016). In the Taita Hills, participants in our study reported increasing frequency and severity of drought and floods, variability of seasons onset, rainfall irregularity and scarcity in the last decade. These local perceptions are not reflected in officials meteorological observations, contrarily to what reported for other studies (Savo et al. 2016, Cuni-Sanchez et al. 2018). The discrepancy may be due to inadequate cover of this area by meteorological stations. Furthermore, misperception could derive from misunderstanding of causes and effects (Hitayez et al. 2017) and from attributing to climate change the severity of impacts influenced even by other factors, such as increased population and inadequate land management practices (Pyhälä et al. 2016). In the Jimma study area, participants in our study reported higher stability of climate conditions over the last decades. However, local communities have recently experienced variability of rainfall spatial distribution, and an increase of disease insurgence threatening coffee production, even at higher elevations. A greater access to meteorological information and as well as greater engagement in strategic planning can enhance awareness on potential climate change impacts and readiness for adaptation (Owidi et al. 2015b).

\section{Business as usual scenarios}

In the Taita Hills, agriculture expansion rate has slowed down in the last decade, and shifted to the low zone (Maeda 2012, Heikinheimo 2015). Most land in the middle and middle-high zones is already in use and parcelled in small plots, except the small forest patches hosting endemic and specialist species (Norfolk et al. 2017a). In the business as usual scenario, a concentration of human presence and activities in a relatively small area could trigger a vicious circle of soil degradation and deforestation, and feedback effects on water availability, crop productivity, biodiversity and social conflicts. Higher temperatures contribute to increased growth, survival and reproductive rates of pest insects in the higher altitudes and agro-ecological zones (Mwalusepo et al. 2015), where the crop damages have not been widely experienced earlier. Contemporarily, higher temperatures enhance Silicon assimilation and pest defences in cereals (Calatayud et al. 2016), thus generating new host-pests interactions that would require adaptation of integrated pest management.

In the Jimma area, higher land availability than in the Taita Hills could actually encourage a great upwards expansion of population and maize production as response to temperature increase, threatening the remaining forest cover. Temperature increase by mid-21st century could intensify coffee diseases incidence (Garedew et al. 2017a) and bring in new pests (Jaramillo et al. 2011), therefore, affecting coffee production, and pushing agriculture expansion at higher elevation. Variability of rainfall regime can also influence the coffee berry disease insurgence. Earlier rains onsets can decrease the disease impacts because at the optimal time for the disease infection coffee 
berry are already grown enough to react; rains delay could instead facilitate the disease incidence.

\section{Adaptation scenarios}

In our study, different adaptation strategies have emerged, characterised by different level of reforestation or avoided deforestation in the Taita Hills and Jimma, respectively. Despite constrained between increasingly arid lowlands and limited middle-high lands, the Taita Hills are located in a favourable location, at the cross of renewed international trade routes, which could provide an advantage for the transition towards either a market-based agricultural system or a conservation-recreational business oriented system. To comply with climate change adaptation and sustainable development goals, traditional livelihood systems should be modernised through improved capacity and climate smart agronomic practices (e.g., agroforestry), which could ensure provision services, in particular food and water, without further depleting regulation services and biodiversity (Food and Agriculture Organization of the United Nations (FAO) 2015). However, under the food production scenario the sustainability and system resilience could be at risk over long-term. For example, farmers could be encouraged to grow crops in marginal areas by new technologies availability. Moreover, if farming suitability decreases in the low zone, the mountain regions could attract migrants who are not familiar with the climate smart farming approach. Investment in innovation, education, tourism and services, along with incentive schemes such as watershed service payments and REDD + (Korchinsky et al. 2011) could support efforts for increasing forest cover and enhanced landscape ecosystem service provision, as envisaged in the green integration scenario. This requires a deep transformation of the community behaviours and cultural values, and the development of policies integrated across the elevation gradient, so that income generating activities are increasingly focused on the low zone or elsewhere, resulting in partial re-naturalisation of the landscape. High population density and pressure may undermine the feasibility of adaptive transformation in the Taita Hills. A mixed-scenarios adaptation strategy coupling subsistence to market-based farming transition with gradual re-greening, e.g., through agroforestry expansion, could be more appropriate for ensuring long-term resilience.

Compared to the Taita Hills, the Jimma rural areas are more remote and isolated, far from markets (particularly from coffee auction sites) and tourism routes; pursuing climate change adaptation and system resilience will require greater efforts on the social and ecological system development. On the other hand, lower population density than in the Taita Hills provides higher chances for adaptive transformation and system resilience enhancement. Despite the positive effect of coffee presence in limiting the conversion of forest to annual-crop agriculture, intensification of coffee management under the coffee industry scenario could threaten forest-dependent species biodiversity (Norfolk et al. 2017b), including the genetic diversity of wild coffee (Hylander et al. 2013). Moreover, in the coffee industry scenario farmers feared the increased dependence on food purchasing and on external market price fluctuations. On the contrary, in the agroforestry scenario shading and maintaining forested land cover around coffee plots can mitigate the impacts of temperature increase (Garedew et al. 2017b) with positive cascade effects on decreasing coffee berry disease incidence (Bedimo et al. 2008) and other ecosystem services (Cerda et al. 2016). Selection of shading tree can contribute to climate regulation through carbon sequestration, and potentially generate payments from carbon markets (Denu et al. 2016). Expansion of agroforestry system is also expected to provide better food nutritional value, allowing cultivation of fruits and beans along with cereals, and maintain diversification of cash crops.

The presented adaptation scenarios may apply more generally to African mountain socio-ecological systems facing climate change along with sustainable development challenges (Leal Filho et al. 2017). Agroforestry has potential for overcoming trade-offs across ecosystem services and biodiversity, and support communities adaptation capacity and resilience. Several barriers have stopped its expansion across Africa, including the productive and environmental performance, socio-cultural and political prerequisites, and opportunity cost (Mbow et al. 2014). Our findings suggest that in absence of a readiness processes for anticipating potential climate crises and barriers to adaptation, such as those supported by place-based scenario analysis, smallholder farmers may even abandon the existing agroforestry systems, to open up more land for staple crops and ensuring food security. Alternatively, in montane areas suitable for high value cash crops, climate changes impacts may accelerate the replacement of traditional farming systems by commercial farming. While food access could be enhanced by wages security, food security is actually a result of complex synergies of economic, social, and cultural factors (Dam Lam et al. 2017).

\section{Conclusions}

Future trajectories of socio-ecological systems in tropical mountain ecosystem will largely depend on societal willingness and capacity, at different levels, to undertake the changes needed to reduce the impacts of climate and land management change. Through a participatory scenario development process we engaged mountain communities 
in the Taita Hills, Kenya and Jimma, Ethiopia in envisioning potential impacts of global climate change and local land changes, and identifying and negotiating tradeoffs between desirable and undesirable goals. We found that business as usual coping strategies could lead to disruption of local livelihoods system in the two study areas. Different alternative adaptation pathways emerged that would generally require either transformation of traditional farming, e.g., a move to modern food production or agroforestry expansion, or a radical shift to new livelihood systems, e.g., a migration of human activities from higher to lower elevation or shift to coffee plantations. These alternatives may present trade-offs for ecosystem services, in particular between provisioning, regulating services, and biodiversity. The identified adaptation alternatives could possibly inform climate change adaptation and mitigation strategies. Our studies highlighted the importance of developing transdisciplinary approaches in sustainability science and in building local capability to anticipate an uncertain future, and of promoting synergies between climate, development and conservation actions at local scale.

Acknowledgements We are grateful to the workshops participants in the Taita Hills and Jimma. We acknowledge the logistic and administrative support from the College of Agriculture and Veterinary Medicine of Jimma University, the Taita Environmental Research and Resource Arc (TERRA), in particular Mr Mwadime Njombe, the International Centre of Insect Physiology and Ecology (ICIPE), the University of York, and the University of Helsinki. This study was funded by the Ministry of Foreign Affairs of Finland through the CHIESA and AFERIA projects.

Open Access This article is distributed under the terms of the Creative Commons Attribution 4.0 International License (http://creative commons.org/licenses/by/4.0/), which permits unrestricted use, distribution, and reproduction in any medium, provided you give appropriate credit to the original author(s) and the source, provide a link to the Creative Commons license, and indicate if changes were made.

\section{References}

Adhikari U, Nejadhashemi AP, Woznicki SA (2015) Climate change and Eastern Africa: a review of impact on major crops. Food Energy Secur 4:110-132

Bedimo JAM, Njiayouom I, Bieysse D, Ndoumbè Nkeng M, Cilas C, Nottéghem JL (2008) Effect of shade on Arabica Coffee Berry disease development: toward an agroforestry system to reduce disease impact. Phytopathology 98:1320-1325

Brink AB, Bodart C, Brodsky L, Defourney P, Ernst C, Donney F, Lupi A, Tuckova K (2014) Anthropogenic pressure in East Africa-monitoring 20 years of land cover changes by means of medium resolution satellite data. Int $\mathrm{J}$ Appl Earth Obs Geoinf 28:60-69. https://doi.org/10.1016/j.jag.2013.11.006

Calatayud PA, Njuguna E, Mwalusepo S, Gathara M, Okuku G, Kibe A, Musyoka B, Williamson D, Ong'amo G, Juma G, Johansson T, Subramanian S, Gatebe E, Le Ru B (2016) Can climate-driven change influence silicon assimilation by cereals and hence the distribution of Lepidopteran stem borers in East Africa? Agric Ecosyst Environ 224:95-103

Canning D, Raja Sangeeta, Yazbeck Abdo S (eds) (2015) Africa's demographic transition: dividend or disaster? Africa development forum series. World Bank, Washington. https://doi.org/10. 1596/978-1-4648-0489-2

Capitani C, Mukama K, Mbilinyi B, Munishi P, Burgess N, Platts PJ, Sallu S, Marchant R (2016) From local scenarios to national maps: a participatory framework for envisioning the future applied to Tanzania. Ecol Soc 21(3):4

Cerda R, Allinne C, Gary C, Tixier P, Harvey CA, Krolczyk L, Mathiot C, Clément E, Aubertot J-N, Avelino J (2016) Effects of shade, altitude and management on multiple ecosystem services in coffee agroecosystems. Eur J Agron 82:308-319

Clark BJF, Pellikka PKE (2009) Landscape analysis using multiscale segmentation and object oriented classification. In: Röder A, Hill $\mathrm{J}$ (eds) Recent advances in remote sensing and geoinformation processing for land degradation assessment. ISPRS book series in photogrammetry, remote sensing and spatial information sciences. Taylor and Francis Group, London, UK, pp 323-342

CSA (Central Statistical Agency of Ethiopia) (2007) Population and Housing Census of Ethiopia 2007: Statistical Report, Federal Democratic Republic of Ethiopia. Central Statistical Agency, Addis Ababa

Cuni-Sanchez A, Omeny P, Pfeifer M, Olaka L, Mamo MB, Marchant R, Burgess ND (2018) Climate change and pastoralists: perceptions and adaptation in montane Kenya. Clim Dev 12:1756-5529

Dam Lam R, Boafo YA, Degefa S, Gasparatos A, Saito O (2017) Assessing the food security outcomes of industrial crop expansion in smallholder settings: insights from cotton production in Northern Ghana and sugarcane production in central Ethiopia. Sustain Sci 12:677-693

Denu D, Belude T (2012) Floristic composition of traditional sacred landscapes in Bedelle Woreda, Illubabor zone, Oromia regional state, Ethiopia. Ethiop J Educ Sci 8:75-91

Denu D, Platts PJ, Kelbessa E, Gole TW, Marchant R (2016) The role of traditional coffee management in forest conservation and carbon storage in the Jimma Highlands, Ethiopia. Trees Livelihoods 25(4):226-238

Fleurbaey M, Kartha S, Bolwig S, Chee YL, Chen Y, Corbera E, Lecocq F, Lutz W, Muylaert MS, Norgaard RB, Okereke C, Sagar A (2014) Sustainable development and equity. In: Edenhofer O, Pichs-Madruga R, Sokona Y, Minx JC, Farahani E, Kadner S, Seyboth K, Adler A, Baum I, Brunner S, Eickemeier P, Kriemann B, Savolainen J, Schlömer S, von Stechow C, Zwickel T (eds.) Climate change 2014: mitigation of climate change. Working group III contribution to the fifth assessment report of the Intergovernmental Panel on Climate Change. Cambridge University Press, New York, pp. 238-350. ISBN 9781107058217

Food and Agriculture Organization of the United Nations (FAO) (2015) Scoping study on climate-smart agriculture in Kenya. Smallholder integrated crop-livestock farming systems. Mitigation of Climate Change in Agriculture (MICCA) programme background report 8. FAO, Rome

Ford JD, Berrang-Ford L, Aa Bunce, McKay C, Irwin M, Pearce T (2015) The status of climate change adaptation in Africa and Asia. Reg Environ Chang 15(5):801-814

Garedew W, Lemessa F, Pinard F (2017a) Assessment of berry drop due to coffee berry disease and non-CBD factors in Arabica coffee under farmers fields of Southwestern Ethiopia. Crop Prot 98:276-282

Garedew W, Hailu BT, Lemessa F, Pelikka P, Pinard F (2017b) Coffee shade tree management: an adaptation option for climate change impact for small scale coffee growers in south-west Ethiopia. In: Leal Filho W, Simane B, Kalangu J, Wuta M, 
Munishi P, Musiyiwa K (eds) Climate change adaptation in Africa. Fostering Resilience and Capacity to Adapt. Climate Change Management series. Springer International Publishing, Cham, Switzerland. pp 647-659

Gasparatos A, Takeuchi K, Elmqvist T, Fukushi K, Nagao M, Swanepoel F, Swilling M, Trotter D, von Blottnitz H (2017) Sustainability science for meeting Africa's challenges: setting the stage. Sustain Sci 12:635-640

Hailu BT, Maeda EE, Hurskainen P, Pellikka P (2014) Object-based image analysis for distinguishing indigenous and exotic forests in coffee production areas of Ethiopia. Appl Geom 6(4):207-214

Hailu BT, Maeda EE, Heiskanen J, Pellikka P (2015a) Reconstructing pre-agricultural expansion vegetation cover of Ethiopia. Appl Geogr 62:357-365

Hailu BT, Maeda EE, Pellikka P, Pfeifer M (2015b) Identifying potential areas of understorey coffee in Ethiopia's highlands using predictive modelling. Int J Rem Sens 36(11):2898-2919

Heikinheimo V (2015) Impact of land change on aboveground carbon stocks in the Taita Hills, Kenya". Master's thesis geography Geoinformatics. University of Helsinki, Department of Geosciences and Geography Division of Geography, Helsinki

Hitayez P, Wale E, Ortmann G (2017) Assessing farmers' perceptions about climate change: a double-hurdle approach. Clim Risk Manag 17:123-138

Hylander K, Nemomissa S, Delrue J, Enkosa W (2013) Effects of coffee management on deforestation rates and forest integrity. Conserv Biol 27:1031-1040

IPBES (2016) The methodological assessment report on scenarios and models of biodiversity and ecosystem services. In: Ferrier S, Ninan KN, Leadley P, Alkemade R, Acosta LA, Akçakaya HR, Brotons L, Cheung WWL, Christensen V, Harhash KA, KabuboMariara J, Lundquist C, Obersteiner M, Pereira HM, Peterson G, Pichs-Madruga R, Ravindranath N, Rondinini C, Wintle BA (eds) Secretariat of the intergovernmental science-policy platform on biodiversity and ecosystem services. IPBES Experts, Bonn

IPCC (2014) Summary for policy makers. In: Barros VR, Field CB, Dokken DJ, Mastrandrea MD, Mach KJ, Bilir TE, Chatterjee M, Ebi KL, Estrada YO, Genova RC, Girma B, Kissel ES, Levy AN, MacCracken S, Mastrandrea PR, White LL (eds) Climate change 2014: impacts, adaptation, and vulnerability. Part A: global and sectoral aspects. Contribution of working group II to the fifth assessment report of the intergovernmental panel on climate change. Cambridge University Press, Cambridge, pp 1-32

Jaramillo J, Muchugu E, Vega FE, Davis A, Borgemeister C, ChabiOlaye A (2011) Some Like It Hot: the influence and implications of climate change on coffee berry borer (Hypothenemus hampei) and coffee production in East Africa. PLoS One 6(9):e24528

Jarvis A, Reuter HI, Nelson A, Guevara E (2008) Hole-filled SRTM for the globe Version 4, available from the CGIAR-CSI SRTM 90 m Database. http://srtm.csi.cgiar.org. Accessed Dec 2016

Joakim EP, Mortsch L, Oulahen G (2015) Using vulnerability and resilience concepts to advance climate change adaptation. Environ Hazards 14(2):137-155

Jurgilevich A, Räsänen A, Groundstroem F, Juhola S (2017) A systematic review of dynamics in climate risk and vulnerability assessments. Environ Res Lett 12:3002

Kenya National Bureau of Statistics (KNBS) (2009) Kenya population and housing census. Kenya National Bureau of Statistics, Nairobi

Kishita Y, Hara K, Uwasu M, Umeda Y (2016) Research needs and challenges faced in supporting scenario design in sustainability science: a literature review. Sustain Sci 11(2):331-347

Kok MTJ, Kok K, Peterson GD, Hill R, Agard J, Carpenter SR (2017) Biodiversity and ecosystem services require IPBES to take novel approach to scenarios. Sustain Sci 12(1):177-181
Korchinsky M, Freund J, Cowan L, Dodson R (2011) The Kasigau corridor REDD project phase II-the community ranches. Project design document. Wildlife Works, Rukinga, Kenya

Leal Filho W, Simane B, Kalangu J, Wuta M, Munishi P, Musiyiwa K (eds) (2017) Climate change adaptation in Africa. Fostering Resilience and Capacity to Adapt. Climate Change Management series. Springer International Publishing, Cham, Switzerland. https://doi.org/10.1007/978-3-319-49520-0

Lloyd CT, Sorichetta A, Tatem AJ (2017) High resolution global gridded data for use in population studies. Sci Data 4:170001. https://doi.org/10.1038/sdata.2017.1

Maeda EE (2012) The future of environmental sustainability in the Taita Hills, Kenya: assessing potential impacts of agricultural expansion and climate change. Fennia 190(1):41-59

Marchant R, Richer S, Boles O, Capitani C, Courtney-Mustaphi C, Prendergast M, Stump D, Lane P, Wynne-Jones S, Ferro Vázquez C, Wright D, Boivin N, Lang C, Kay A, Phelps L, Fuller D, Widgren M, Punwong P, Lejju J, Gaillard-Lemdahl M-J, Morrison KD et al (2018) Drivers and trajectories of land cover change in East Africa: human and environmental interactions from 6000 years ago to present. Earth Sci Rev, Accepted Manuscript

Mbow C, Van Noordwijk M, Luedeling E, Neufeldt H, Minang PA, Kowero G (2014) Agroforestry solutions to address food security and climate change challenges in Africa. Curr Opin Environ Sustain 6:61-67

McDowell G, Ford J, Jones J (2016) Community-level climate change vulnerability research: trends, progress, and future directions. Environ Res Lett 11:33001

Mittermeier RA, Turner WR, Larsen FW, Brooks TM, Gascon C (2011) Global biodiversity conservation: the critical role of hotspots. In: Zachos F, Habel J (eds) Biodiversity hotspots. Springer, Berlin, pp 3-22

Mwalusepo S, Tonnang HEZ, Massawe ES, Okuku GO, Khadioli N, Johansson T, Calatayud P-A, Le Ru BP (2015) Predicting the impact of temperature change on the future distribution of maize stem borers and their natural enemies along east African Mountain Gradients using phenology models. PLoS ONE 10(6): 0130427

Ngowi BV, Tonnang HEZ, Mwangi EM, Johansson T, Ambale J, Ndegwa PN et al (2017) Temperature-dependent phenology of Plutella xylostella (Lepidoptera: plutellidae): simulation and visualization of current and future distributions along the Eastern Afromontane. PLoS One 12(3):e0173590

Niang I, Ruppel OC, Abdrabo MA, Essel A, Lennard C, Padgham J, Urquhart T (2014) Africa. In: Barros VR, Field CB, Dokken DJ, Mastrandrea MD, Mach KJ, Bilir TE, Chatterjee M, Ebi KL, Estrada YO, Genova RC, Girma B, Kissel ES, Levy AN, MacCracken S, Mastrandrea PR, White LL (eds) Climate change 2014: impacts, adaptation, and vulnerability. Climate change 2014: impacts, adaptation, and vulnerability. Cambridge University Press, Cambridge, pp 1199-1265

Norfolk O, Jung M, Platts PJ, Marchant R (2017a) Birds in the matrix: The role of agriculture in avian conservation in the Taita Hills. Afr J Ecol, Kenya. https://doi.org/10.1111/aje.12383

Norfolk O, Asale A, Temesgen T, Yewhalaw D (2017b) Diversity and composition of tropical butterflies along an Afromontane agricultural gradient in the Jimma highlands, Ethiopia. Biotropica 49(3):346-354

Ntiri ES, Calatayud PA, Van Den Berg J, Schulthess F, Le Ru BP (2016) Influence of temperature on intra- and interspecific resource utilization within a community of Lepidopteran maize stemborers. PLoS One 11(2):e0148735

O'Brien K, Eriksen S, Schjolden LP, Nygaard A (2007) Why different interpretations of vulnerability matter in climate change discourses. Clim Policy 7:73-88 
Ovalle-Rivera O, Läderach P, Bunn C, Obersteiner M, Schroth G (2015) Projected shifts in coffea arabica suitability among major global producing regions due to climate change. PLoS One 10(4):e0124155

Owidi E, Johansson T, Ndonye S (2015a) Community-based climate change adaptation action plan for the Taita Hills 2015-2019. Ministry for Foreign Affairs of Finland, Nairobi

Owidi E, Johansson T, Ndonye S (2015b) Community-based climate change adaptation action plan for the Jimma highlands 2015-2019. Ministry for Foreign Affairs of Finland, Nairobi

Pellikka PK, Lötjönen M, Siljander M, Lens L (2009) Airborne remote sensing of spatiotemporal change (1955-2004) in indigenous and exotic forest cover in the Taita Hills, Kenya. Int J Appl Earth Obs Geoinf 11(4):221-232

Platts PJ, Omeny PA, Marchant R (2015) AFRICLIM: high-resolution climate projections for ecological applications in Africa. Afr J Ecol 53:103-108

Pyhälä A, Fernández-Llamazares Á, Lehvävirta H, Byg A, RuizMallén I, Salpeteur M, Thornton TF (2016) Global environmental change: local perceptions, understandings, and explanations. Ecol Soc 21(3):25
Räsänen A, Juhola S, Nygren A, Käkönen M, Kallio M, Monge Monge A, Kanninen M (2016) Climate change, multiple stressors and human vulnerability: a systematic review. Reg Environ Chang 16:2291

Savo V, Lepofsky D, Benner JP, Kohfeld KE, Bailey J, Lertzman K (2016) Observations of climate change among subsistenceoriented communities around the world. Nat Clim Chang $6: 462-473$

Schmitz C, van Meijl H, Kyle P, Nelson GC, Fujimori S, Gurgel A, Havlik P et al (2014) Land-use change trajectories up to 2050: insights from a global agro-economic model comparison. Agric Econ 45(1):69-84

Teketay D (1999) History, botany and ecological requirements of coffee. J Ethiop Wild Nat Hist Soc 20:28-50

Toniutti L, Breitler J-C, Etienne H, Campa C, Doulbeau S, Urban L, Lambot C, Pinilla J-CH, Bertrand B (2017) Influence of environmental conditions and genetic background of arabica coffee (C. arabica $\mathrm{L})$ on leaf rust (Hemileia vastatrix) pathogenesis. Front. Plant Sci 8:2025

Weber EU (2016) What shapes perceptions of climate change? New research since 2010 WIREs. Clim Change 7:125-134

\section{Affiliations}

\section{Claudia Capitani ${ }^{1}$ (i) Weyessa Garedew ${ }^{2} \cdot$ Amsalu Mitiku $^{2} \cdot$ Gezahegn Berecha $^{2} \cdot$ Binyam Tesfau Hailu ${ }^{3}$. Janne Heiskanen ${ }^{4} \cdot$ Pekka Hurskainen $^{4} \cdot$ Philip J. Platts $^{5} \cdot$ Mika Siljander $^{4} \cdot$ Fabrice Pinard $^{6} \cdot$ Tino Johansson $^{4}$. Robert Marchant ${ }^{1}$}

1 Environment Department, University of York, York, UK

2 College of Agriculture and Veterinary Medicine, Jimma University, Jimma, Ethiopia

3 School of Earth Sciences, College of Natural Sciences, Addis Ababa University, Addis Ababa, Ethiopia
4 Department of Geosciences and Geography, University of Helsinki, Helsinki, Finland

5 Department of Biology, University of York, York, UK

6 Cirad, UR Bioagresseurs, Montpellier, France 